\title{
PENERAPAN METODE PEMBELAJARAN COOPERATIF LEARNING TIPE ZIGSA W UNTUK MENINGKATKAN MOTIVASI DAN HASIL BELAJAR SISWA KELAS VI SD RK NOMOR 3 SIBOLGA PADA SUB TEMA TUMBUHAN SAHABATKU
}

\author{
Juni Agus Simaremare \\ ${ }^{1}$ Universitas HKBP Nommensen Pematangsiantar \\ Email: simaremarejuniagus@gmail.comı
}

\begin{abstract}
ABSTRAK
Tujuan Penelitian ini adalah untuk meningkatkan motivasi dan hasil belajar siswa melalui metode pembelajaran Cooperatif Learning Tipe Zigsaw pada sub tema tumbuhan sahabatku kelas VI SD RK Nomor 3 Sibolga. Jenis penelitian adalah penelitian tindakan kelas (Classroom Action Research). Penelitian dilaksanakan dengan kolaborasi antara peneliti, guru dan melibatkan keaktifan belajar siswa. Subjek penelitian siswa kelas VI SD RK Nomor 3 Sibolga tahun pelajaran 2018/2019 yang berjumlah 32 siswa. Teknik pengumpulan data menggunakan observasi dan angket sederhana. Prosedur penelitian meliputi tahap: (a) perencanaan tindakan, (b) pelaksanaan tindakan, (c) observasi dan interpretasi, dan (d) analisis dan refleksi. Berdasarkan hasil penelitian, metode pembelajaran Cooperatif Learning Tipe Zigsaw dapat meningkatkan motivasi belajar siswa. Penerapan metode pembelajaran Cooperatif Learning Tipe Zigsaw Berdasarkan hasil penelitian tindakan kelas yang telah dilakukan di kelas VI SD RK Nomor 3 Sibolga dapat disimpulan bahwa penerapan pembelajaran kooperatif Jigsaw dapat meningkatkan motivasi belajar siswa pada sub tema tumbuhan sahabatku. Kesimpulan hipotesis dapat diterima.
\end{abstract}

Kata kunci : Motivasi Belajar, Hasil Belajar, Metode pembelajaran Cooperatif Learning Tipe Zigsaw

\begin{abstract}
The purpose of this study was to increase students' motivation and learning outcomes through the Zigsaw Type Cooperative Learning learning method on the sub-theme of plants my best friend class VI SD RK Number 3 Sibolga. The type of research is classroom action research (Classroom Action Research). The research was carried out in collaboration between researchers, teachers and involved student learning activities. The research subjects were students of class VI SD RK Number 3 Sibolga for the academic year 2018/2019, totaling 32 students. Data collection techniques using simple observation and questionnaires. The research procedure includes the following stages: (a) action planning, (b) action implementation, (c) observation and interpretation, and (d) analysis and reflection. Based on the research results, the Zigsaw Type Cooperative Learning method can increase


students' learning motivation. Application of the Zigsaw Cooperative Learning method Based on the results of classroom action research that has been carried out in class VI SD RK Number 3 Sibolga, it can be concluded that the application of Jigsaw cooperative learning can increase students' learning motivation in the subtheme of plants my friend. The conclusion of the hypothesis can be accepted.

Keywords: Learning Motivation, Learning Outcomes, Zigsaw Cooperative Learning Method

\section{PENDAHULUAN}

Pendidikan dikatakan berhasil

jika tercapai peningkatan kualitas pendidikan. Peningkatan kualitas pendidikan dapat dilihat dari meningkatnya hasil belajar siswa. Hasil belajar siswa dapat meningkat apabila siswa dapat berhasil dalam belajar. Keberhasilan belajar dipengaruhi oleh beberapa faktor yaitu diri siswa atau lingkungan siswa. Belajar perlu didukung oleh motivasi yang kuat dan konstan. Peran guru sebagai motivator adalah memberi motivasi kepada siswa agar melakukan kegiatan belajar dengan kehendak sendiri sesuai dengan tujuan belajar yang telah ditetapkan kurikulum. Peran guru sebagai fasilitator adalah memfasilitasi siswa agar dapat belajar dengan mendayagunakan potensi yang dimiliki. Cara yang dapat dilakukan oleh guru untuk memfasilitasi siswa antara lain dengan menciptakan lingkungan belajar yang kondusif dan memberikan bimbingan pada saat kegiatan belajar.

\section{SD RK Nomor 3 Sibolga} merupakan salah satu sekolah yang mempunyai fasilitas yang cukup memadai dan input siswa dengan hasil belajar yang bervariasi. Hasil belajar yang bervariasi disebabkan karena motivasi dalam pembelajaran beraneka ragam. Hasil observasi awal diperoleh jumlah rata-rata siswa yang terlambat masuk kelas $15 \%$ (6 orang), siswa yang tidak mengerjakan PR atau tugas $40 \%$ (16 orang), siswa yang bertanya mengenai materi pelajaran 2,5\% (1 orang), siswa yang menjawab pertanyaan guru tanpa ditunjuk 5\% (2 orang), siswa yang tidak memperhatikan sewaktu guru menerangkan $40 \%$ (16 orang), siswa yang tidak membawa buku pegangan $30 \%$ (12 orang). Berdasarkan hasil 
tersebut diperoleh kesimpulan sementara bahwa motivasi belajar siswa rendah.

Kesimpulan sementara dapat diperkuat dengan melakukan observasi lanjutan dengan menggunakan indikator motivasi belajar. Setelah dilakukan observasi diperoleh hasil bahwa indikator perhatian siswa mencapai $70 \% \quad(28$ siswa), indikator keaktifan siswa dalam diskusi mencapai $67,5 \%$ (27 siswa), indikator tekun mengerjakan tugas mencapai 72,5\% (29 siswa), indikator senang dalam pemecahan masalah mencapai 5\% (2 siswa), indikator adanya dorongan dan kebutuhan belajar mencapai 2,5\% (1 siswa), indikator percaya diri mencapai $\quad 72,5 \% \quad(29$ siswa). Berdasarkan hasil observasi dapat disimpulkan motivasi belajar siswa rendah. Pemberian angket juga dilakukan kepada siswa untuk lebih menguatkan kesimpulan tersebut. Hasil perhitungan angket adalah sebagai berikut: indikator I yaitu adanya perasaan senang terhadap pembelajaran mencapai 50,75\%, indikator II yaitu adanya hasrat dan keinginan berhasil dalam belajar mencapai $59,83 \%$, indikator III yaitu adanya dorongan dan kebutuhan belajar mencapai $60,38 \%$, indikator IV yaitu tekun mengerjakan tugas mencapai $58,8 \%$, indikator $\mathrm{V}$ yaitu tidak putus asa mencapai 58,13\%, indikator VI yaitu perhatian siswa mencapai $60,13 \%$, indikator VII yaitu keaktifan siswa dalam diskusi mencapai $61 \%$, indikator VIII yaitu senang dalam pemecahan masalah mencapai $61 \%$, indikator IX yaitu percaya diri mencapai 57,8\%, indikator $\mathrm{X}$ yaitu belajar dengan harapan untuk memperoleh penghargaan mencapai $59 \%$ dan indikator XI yaitu belajar karena adanya kegiatan yang menarik mencapai $61,13 \%$. Rata indikator aspek I yaitu dorongan internal mencapai $58,65 \%$ dan aspek II yaitu dorongan eksternal mencapai $60,06 \%$. Berdasarkan hasil tersebut dapat ditarik kesimpulan bahwa masalah di kelas tersebut adalah rendahnya motivasi belajar siswa karena rata-rata indikator tersebut pada tiap aspek masih menunjukkan persentase angka yang rendah.

Hasil wawancara yang dilakukan dengan guru menyatakan 
bahwa motivasi belajar siswa rendah.

Hasil wawancara dengan siswa menyatakan bahwa siswa kurang tertarik dengan pembelajaran, sehingga menandakan bahwa motivasi belajar siswa rendah. Berdasarkan hasil observasi, pemberian angket dan wawancara diperoleh hasil bahwa motivasi belajar siswa rendah, sehingga dapat ditarik kesimpulan bahwa masalah di kelas tersebut adalah rendahnya motivasi belajar siswa dalam pembelajaran.

Penyebab dari rendahnya motivasi belajar siswa adalah metode pembelajaran yang diterapkan masih berpusat pada guru sehingga membosankan bagi siswa dan membuat siswa kurang termotivasi mengikuti pembelajaran. Guru sebagai pengajar perlu mengatasi hal tersebut, salah satunya dengan mencoba strategi pembelajaran yang lebih menarik bagi siswa dan tidak membosankan agar dapat membangkitkan motivasi belajar siswa dalam pembelajaran. Motivasi belajar siswa yang meningkat membuat siswa belajar dengan sungguh-sungguh sehingga dapat berhasil dalam proses belajar mengajar. Pembelajaran kooperatif Jigsaw dapat diterapkan untuk meningkatkan motivasi belajar siswa dalam pembelajaran.

Pembelajaran kooperatif merupakan model pembelajaran yang lebih banyak melibatkan interaksi aktif antar siswa dengan siswa, siswa dengan guru maupun siswa dengan lingkungan belajar. Siswa belajar bersama-sama dan memastikan bahwa setiap anggota kelompok telah benar - benar menguasai materi yang sedang dipelajari. Beberapa keuntungan yang bisa diperoleh dari penerapan pembelajaran kooperatif yaitu siswa dapat mencapai hasil belajar yang bagus. Pembelajaran kooperatif dapat meningkatkan motivasi belajar siswa yang merupakan salah satu faktor yang mempengaruhi hasil belajar. Siswa juga dapat menerima dengan senang hati pembelajaran yang digunakan karena adanya kontak fisik antar siswa, serta dapat mengembangkan kemampuan sosial siswa.

Terdapat banyak tipe dalam pembelajaran kooperatif salah satunya adalah Jigsaw. Pembelajaran 
kooperatif Jigsaw membagi siswa menjadi beberapa kelompok dengan karakteristik yang heterogen. Anggota dari berbagai kelompok yang berbeda memiliki tanggung jawab untuk mempelajari suatu bahan materi yang sama dan selanjutnya berkumpul dalam kelompok ahli untuk saling membantu mengkaji bagian bahan tersebut. Selanjutnya siswa yang berada dalam kelompok ahli kembali ke kelompok semula untuk mengajar anggota lain mengenai materi yang telah dipelajari dalam kelompok ahli. Siswa dievaluasi secara individual mengenai bahan yang telah dipelajari setelah diadakan diskusi.

Adanya tanggung jawab mengajarkan materi kepada anggota kelompok lain pada pembelajaran kooperatif Jigsaw dapat meningkatkan dorongan dan kebutuhan belajar serta melatih rasa percaya diri siswa. Melalui pembelajaran kooperatif Jigsaw ketekunan siswa untuk mengerjakan tugas dapat ditingkatkan, karena siswa harus melaksankan tugas membaca agar dapat mengajarkan materi kepada anggota kelompok sehingga motivasi belajar siswa bisa ditingkatkan.

Slavin (2008: 237) menyatakan bahwa pembelajaran kooperatif Jigsaw menjadikan siswa termotivasi untuk belajar karena skor-skor yang dikontribusikan siswa kepada tim didasarkan pada sistem skor perkembangan individual, dan siswa yang skor timnya meraih skor tertinggi akan menerima sertifikat atau bentuk-bentuk rekognisi tim yang lain sehingga siswa termotivasi untuk mempelajari materi dengan baik dan untuk bekerja keras serta aktif dalam kelompok ahli supaya dapat membantu tim melakukan tugas dengan baik. Tiap individu memberi kontribusi pada pencapaian tujuan anggota yang lain pada pembelajaran kooperatif tipe Jigsaw.

Pembelajaran kooperatif (Cooperativ learning) adalah pendekatan pembelajaran yang berfokus pada penggunaan kolompok kecil siswa untuk bekerja sama. Pendekatan pembelajaran kooperatif memaksimalkan kondisi belajar untuk mencapai tujuan belajar (Sugiyanto,2008: 35). 
Nurhadi (2005: 112) menyatakan bahwa pembelajaran kooperatif dipandang efektif. Manusia memiliki derajat potensi, latar belakang historis, serta harapan masa depan yang berbeda-beda. Manusia dapat saling mencerdaskan karena perbedaan itu. Pembelajaran kooperatif menciptakan interaksi yang saling mencerdaskan sehingga tercipta masyarakat belajar (learning community). Siswa tidak hanya belajar dari guru, tetapi juga dari sesama siswa.

Menurut Slavin (2008: 4) pembelajaran kooperatif merujuk pada berbagai macam metode pembelajaran dimana siswa bekerja dalam kelompok - kelompok kecil untuk saling membantu satu sama lain dalam mempelajari materi pembelajaran. Pembelajaran kooperatif menekankan pada kerja sama siswa dalam kelompok. Siswa diharapkan dapat saling membantu, saling mendiskusikan dan berargumentasi untuk mengasah pengetahuan yang dimiliki dan dapat mengatasai kesenjangan dalam pemahaman diantara siswa.
Anita Lie (2004: 31) mengemukakan bahwa untuk mencapai hasil yang maksimal, terdapat lima prinsip pembelajaran kooperatif yang harus diterapkan yaitu: a) saling ketergantungan positif; b) tanggung jawab perseorangan; c) tatap muka; d) komunikasi antar anggota; e) evaluasi proses kelompok.

\section{METODE PENELITIAN}

Penelitian ini dilaksanakan pada siswa kelas VI SD RK Nomor 3 Sibolga. Jenis penelitian adalah Penelitian Tindakan Kelas (Classroom Action Research). Penelitian dilaksanakan dengan kolaborasi antara peneliti, guru dan melibatkan keaktifan belajar siswa. Subjek penelitian siswa kelas VI SD RK Nomor 3 Sibolga tahun pelajaran 2018/2019 yang berjumlah 32 siswa. Teknik pengumpulan data menggunakan observasi dan angket sederhana. Prosedur penelitian meliputi tahap: (a) perencanaan tindakan, (b) pelaksanaan tindakan, (c) observasi dan interpretasi, dan (d) analisis dan refleksi.

\section{HASIL DAN PEMBAHASAN}


Kondisi awal siswa diketahui melalui observasi pada proses pembelajaran di kelas. Hasil observasi menunjukkan bahwa dari 40 siswa, jumlah rata-rata siswa yang terlambat masuk kelas 15\% (6 orang), siswa yang tidak mengerjakan tugas atau PR 40\% (16 orang), siswa yang bertanya mengenai materi pelajaran $2,5 \%$ (1 orang), siswa yang menjawab pertanyaan guru tanpa ditunjuk 5\% (2 orang), siswa yang tidak memperhatikan sewaktu guru menerangkan $40 \%$ (16 orang), siswa yang tidak membawa buku pegangan $30 \%$ (12 orang). Kesimpulan sementara berdasarkan hasil observasi tersebut adalah motivasi belajar siswa rendah.

Rata-rata persentase indikator aspek I yaitu dorongan internal mencapai $73,49 \%$. Rata-rata indikator aspek II, yaitu dorongan eksternal mencapai $73,81 \%$. Target pada siklus I belum tercapai. Target untuk angket motivasi belajar siswa adalah rata-rata indikator tiap aspek mencapai lebih dari atau sama dengan $75 \%$.

Penerapan pembelajaran kooperatif Jigsaw pada siklus I sudah terjadi peningkatan motivasi belajar siswa dalam pembelajaran. Meningkatnya motivasi belajar siswa dalam pembelajaran pada siklus I disebabkan diterapkanya pembelajaran kooperatif Jigsaw dalam proses pembelajaran. Karakteristik yang khas pada pembelajaran ini adalah setiap siswa memiliki tanggung jawab untuk mengajarkan sesuatu kepada siswa lain. Hasil wawancara dengan beberapa siswa diperoleh bahwa penerapan metode pembelajaran yang belum pernah dilakukan sebelumnya ini telah meningkatkan ketertarikan siswa terhadap kegiatan pembelajaran, sehingga perhatian siswa terhadap pembelajaran juga meningkat. Adanya tanggung jawab kepada masing-masing siswa untuk mengajarkan sesuatu kepada siswa lain telah meningkatkan dorongan kebutuhan siswa untuk belajar. Setiap siswa harus mengajarkan sesuatu sebaik mungkin kepada siswa lain agar masing-masing siswa dalam anggota kelompok dapat memahami apa yang diajarkan, sehingga diakhir pembelajaran, dapat mengerjakan kuis dan dapat meraih skor tertinggi. Adanya tuntutan tersebut telah 
meningkatkan dorongan siswa untuk belajar. Penerapan pembelajaran kooperatif Jigsaw melibatkan siswa untuk berperan aktif dan dapat mengatasi kebosanan siswa terhadap metode pembelajaran yang biasa digunakan oleh guru, sehingga timbul kesenangan dari diri siswa pada saat kegiatan pembelajaran.

Hasil wawancara dengan guru pelajaran diperoleh bahwa secara umum respon siswa positif terhadap penggunaan pembelajaran kooperatif Jigsaw pada kegiatan pembelajaran. Penggunaan pembelajaran tersebut pada awalnya membuat siswa merasa agak bingung, namun pada pertemuan selanjutnya, siswa sudah tidak merasa bingung. Berdasarkan uraian di atas, dapat disimpulkan bahwa kelebihan dari penerapan pembelajaran kooperatif Jigsaw adalah penerapan pembelajaran kooperatif Jigsaw efektif untuk meningkatkan motivasi belajar siswa dalam pembelajaran.

Pelaksanaan tindakan pada siklus II ini dilaksanakan dalam tiga kali tatap muka. Pelaksanaan tindakan pada siklus II merupakan hasil refleksi tindakan dari siklus I. Refleksi dari siklus I bertujuan untuk memperbaiki kekurangankekurangan pelaksanaan tindakan sebelumnya dan membutuhkan upaya perbaikan pada siklus II.

Upaya perbaikan yang direncanakan pada siklus I dilakukan pada siklus II. Upaya perbaikan yang pertama adalah guru memotivasi siswa dengan memberi pertanyaanpertanyaan pada awal pembelajaran. Tujuannya adalah untuk membuat siswa lebih memiliki rasa ingin tahu untuk mempelajari materi, sehingga siswa akan termotivasi dan berantusias untuk mempelajari materi tersebut dari awal. Yang kedua adalah guru mencoba membuat suasana menjadi lebih akrab dan komunikatif pada sesi dengan guru di akhir pelajaran, serta memberikan motivasi dengan intensitas yang lebih tinggi kepada siswa sehingga siswa merasa nyaman dalam pembelajaran. Guru juga memberikan nilai bagi siswa yang mau bertanya atau menjawab pertanyaan. Tujuannya adalah membuat siswa berani dan percaya diri untuk mengajukan pertanyaan, menjawab pertanyaan, menyampaikan pendapat di depan umum. Ketiga yaitu guru lebih 
mengingatkan lagi tentang pentingnya kerja sama dalam

kelompok, karena keberhasilan individu ditentukan oleh keberhasilan kelompok. Tujuannya adalah agar siswa lebih meningkatkan kerja sama kelompok. Berikutnya adalah guru lebih bersikap tegas kepada siswa, sehingga siswa tidak seenaknya dalam pembelajaran.

Proses pembelajaran yang diterapkan pada tindakan II ini pada dasarnya masih sama seperti halnya pada siklus I yaitu menggunakan pembelajaran kooperatif Jigsaw. Hal yang membedakan pembelajaran pada siklus II ini adalah upaya perbaikan pada proses pembelajaran seperti yang telah dituliskan pada tahap perencanaan tindakan siklus II.

Observasi yang dilakukan pada siklus II masih sama seperti halnya pada siklus I yaitu untuk mendapatkan data tentang motivasi belajar siswa dalam pembelajaran. Hasil pelaksanaan tindakan pada siklus II nilai motivasi belajar siswa dalam pembelajaran untuk siklus II berkisar antara 60\%-100\%. Rata-rata indikator sebesar $82,92 \%$. Rata-rata persentase indikator aspek I yaitu 
seenaknya dalam pembelajaran.

Siswa masih belum bisa bekerja sama secara optimal dengan temannya, sebagai akibat dari pembentukan kelompok yang ditentukan oleh guru, bukan dari keinginan siswa, sehingga siswa belum terbiasa. Siswa hanya akan bertanya kepada guru apabila guru melakukan pendekatan. Respon yang diberikan siswa masih kurang pada saat guru memberi kesempatan bertanya ataupun menanggapi pendapat, sehingga perlu adanya motivasi dari guru yang lebih kuat lagi di awal pembelajaran.

Persentase untuk semua indikator pada siklus II telah mencapai target yang ditetapkan, hal ini disebabkan pada siklus II siswa sudah terbiasa dengan pembelajaran yang digunakan. Siswa sudah bisa menentukan strategi yang baik untuk meraih keberhasilan individu dan kelompok, yaitu siswa harus belajar dengan baik, agar dapat menyampaikan materi dengan baik kepada siswa lain, sehingga disini siswa semakin termotivasi untuk belajar dan aktif dalam pembelajaran di kelas. Guru memotivasi siswa dengan memberi pertanyaan- pertanyaan pada awal pembelajaran, sehingga membuat siswa lebih memiliki rasa ingin tahu untuk mempelajari materi, akibatnya siswa akan termotivasi dan berantusias untuk mempelajari materi tersebut dari awal. Guru mencoba membuat suasana menjadi lebih akrab dan komunikatif pada akhir pembelajaran, serta memberikan motivasi dengan intensitas yang lebih tinggi kepada siswa sehingga siswa merasa nyaman dalam pembelajaran. Guru juga memberikan nilai bagi siswa yang mau bertanya atau menjawab pertanyaan. Guru juga lebih mengingatkan lagi tentang pentingnya kerja sama dalam kelompok, karena keberhasilan individu ditentukan oleh keberhasilan kelompok, sehingga membuat siswa semakin meningkatkan kerja sama dalam kelompoknya. Guru juga lebih bersikap tegas kepada siswa, sehingga siswa tidak seenaknya dalam pembelajaran.

\section{SIMPULAN}

Berdasarkan hasil penelitian tindakan kelas yang telah dilakukan di Kelas VI SD RK Nomor 3 Sibolga VI SD RK Nomor 3 Sibolga dapat ditarik 
simpulan bahwa penerapan pembelajaran kooperatif Jigsaw dapat meningkatkan motivasi belajar siswa dalam pembelajaran.

\section{DAFTAR PUSTAKA}

Abdul Majid. 2007. Perencanaan Pembelajaran

Mengembangkan Standar Kompetensi Guru. Bandung: Remaja Rosdakarya

Anita Lie. 2008. Mempraktekkan cooperative learning di ruang kelas. Jakarta: Gramedia

Dimyati dan Mujiono. 1999. Belajar dan Pembelajaran. Jakarta: Depdikbud dan Rineka Cipta.

Doymus, Kemal. 2009. Effects of Two Cooperative Learning Strategies on Teaching and Learning of Thermochemistry. World Applied Sciences Journal. IDOSI. Vol 7 (1): 3442

Gene L.Wilkinson. 1984. Media dalam Pembelajaran, Penelitian Selama 60 Tahun. Jakarta: Rajawali

Hamzah B Uno. 2008. Teori Motivasi dan Pengukurannya Analisis di Bidang Pendidikan. Jakarta: Bumi Aksara.

Hisyam Zaini, Bermawy
Munthe dan Sekar Ayu
Aryani.2007.Strategi
Pembelajaran
Aktif.Yogyakartya:CSTD

Ike Nurfadilah. 2006. Efektifitas Penggunaan Metode Jigsaw Learning Dalam Pembelajaran Agama Islam (PAI) di SMP Negeri 13 Malang.(online) (http://sukses-skripsi.co, diakses 15 Desember 2010)

Isjonidan Mohd.Arif.Hj.Ismail. 2008. Model-model Pembelajaran Mutakhir Perpaduan IndinesiaMalaysia.Yogyakarta: Pustaka Pelajar

Ivor K Davis.1987. Pengelolaan Belajar. Jakarta: Rajawali Press.

Kunandar. 2003. Guru Profesional. Jakarta: Rajawali Press

Lexy J Moleong. 2005. Metodologi Penelitian Kualitatif. Bandung: Remaja Rosadakarja

Made Wena. 2009. Strategi Pembelajaran Inovatif Kontemporer. Jakarta: Bumi Aksara.

Mardalis. 1990. Metode Penelitian Suatu Pendekatan Proposal. Jakarta: Bumi Aksara

Mattew B Miles\&A Michael Huberman. 1992. Analisa Data Kualitatif: Buku Sumber Tentang Metode- metode Baru. Jakarta: UI Press.

Mel Siberman. 2009. Active Learning: $101 \quad$ Strategi Pembelajarn Aktif. Yogyakarta: Pustaka Insan Madani. 
Mubbin Syah. 2005. Psikologi Pendidikan Dengan Pendekatan Baru. Bandung: Remaja Rosdakarya

Mulyani Sumatri dan Johar Permana,H. 2001. Strategi Belajar Mengajar. Bandung: CV Maulana

Nana Syaodih Sukmadinata. 2004. Landasan Psikologi Proses Pendidikan. Bandung: Remaja Rosdakarya.

Ngalim Purwanto. 1990.Psikologi Pendidikan. Bandung: Remaja Rosdakarya

Norintan, A. M. 2008. Learning through teaching and sharing in

Pedoman Bagi Guru dan Calon Guru. Jakarta: Rajawali.

Slameto. 1995. Belajar dan Faktorfaktor yang Mempengaruhinya. Jakarta: Rineka Cipta

Slavin. 2008. Cooperative Learning (Cooperative Learning).Alih bahsa : Nurlita Yusron.. Bandung: Nusa Media

Suhaenal Suparno. 2000. Bangun Kompetensi Belajar.Jakarta: Direktorat Pendidikan Tinggi Depdiknas

Sutopo. 2002. Metode Penelitian Kualitatif. Surakarta: Sebelas Maret University Press. the jigsaw classroom. The Journal of Annals of Dentistry. University of Malaya.Vol 15 (2): $71-76$

Nurhadi. 2004. Kurikulum 2004 (Pertanyaan dan Jawaban). Jakarta: PT Gramedia

Oemar Hamalik. 2003. Proses Belajar Mengajar. Jakarta: Bumi Aksara

Robertus Angkowo dan A.Kosasih. 2007. Optimalisasi Media Pembelajaran. Jakarta: PT Grasindo

Sardiman. 1990. Interaksi dan Motivasi Belajar Mengajar 